\title{
JURNAL BIOEDUKATIKA
}

http://journal.uad.ac.id/index.php/BIOEDUKATIKA 2338-6630 (Print) | 2541-5646 (Online)

\section{Lesson study for learning community: A way of collegial participation of teachers and lecturers}

Check for updates

\section{Dwi Setyawan ${ }^{1, *}$, Tutut Indria Permana ${ }^{2}$, Roimil Latifa ${ }^{3}$}

Biology Education Department, Faculty of Teacher Training and Education, Universitas Muhammadiyah Malang, Indonesia

11 dwis@umm.ac.id *, ${ }^{2}$ tutut.indria@umm.ac.id, ${ }^{3}$ roimillatifa20@gmail.com

* Corresponding author

\begin{tabular}{ll}
\hline \multicolumn{2}{l}{ ARTICLE INFO } \\
\hline Article history \\
Received & November 302018 \\
Revised & March 28 2019 \\
Accepted & April 28 2019
\end{tabular}

Key word:

Collaboration

Collegial participation

Lesson study for learning

community

\begin{abstract}
The Lesson Study for Learning Community (LSLC) has become promising for improving school progress. However, there has not been much assistance in the community of teacher learning and collaboration that should lead to new approaches to increase classroom learning quality. This study aimed to explain how the process of assessing and the implementation LSLC at SMA Negeri 4 Malang. This qualitative descriptive study uses teachers and lecturers as research subjects with an unspecified amount in their participation. The data was obtained by using a monitoring checklist, interview, and documentation of the implementation lesson study. The results showed that the application of LSLC was running well, but at the 'Do' phase, there were still observers who worked not following their assignment procedures, and the involvement of teachers in LSLC activities even less. Therefore, it is suggested to implement LSLC which improve collegial participation of teachers and lecturers.
\end{abstract}

This is an open access article under the CC-BY-SA license.

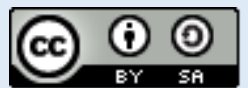

\section{Introduction}

The demand for quality education in the face of $21^{\text {st-Century education has }}$ become commonplace today. Not only the quality of students but also the quality of the teacher. Quality education will be obtained if students and teachers share quality. So there is a need for reformation in the school and the learning process. School reform must have a vision and philosophy of community-based knowledge, multicultural education, modern education that is student-centered with learning abilities and collaborative teaching as a form of professional responsibility.

Learning community is one approach to increasing teacher competency as an effort to prove the quality of teaching carried out. The learning community is so promising for the improvement of progressive schools, through mentoring the learning and collaboration community of teachers, it is hoping that new approaches will emerge to change the quality of classroom learning. According to Sato (2012), The mission of the learning community in schools is to guarantee the learning rights of each student without exception and improve the quality of learning. The professional learning community is expected to provide the opportunity for teachers as educators to look for various collegial learning approaches and then determine the decisions for learning actions (Coenders \& 
Verhoef, 2019). The teachers did not formulate a research question for their research lesson, they did not focus on observing pupil learning, and their lesson was not organized to make colaboration learning (Bjuland \& Mosvold, 2015). According to (Nurwidodo, Hendayana, Hindun, \& Sarimanah, 2018) From the observations of researchers in several partner schools, findings have been finding including; the lack of collaboration in learning, planning that is not collaboratively designing, the implementation of independent learning and reflection on the learning process has never been doing as the root of the problem.

Improving teaching competence as an effort to improve teacher professionalism has been carried out in many countries around the world (Delvaux et al., 2013). Each teacher in the education unit is obliged to develop interactive, inspirational, fun, challenging learning, motivating students to participate actively, and providing sufficient space to work, be creative and independent according to the talents, interests and physical and psychological development of students. Therefore, learning from the teaching process carried out by oneself and others can be the basis for continuous improvement and professional development (Sugiharto, Prayitno, \& Widoretno, 2016). The involvement of teachers in the planning, implementation, and results of learning is an effort to maximize the learning process as a form of teacher professional development based on real experience is a new and actual perspective (Setyawan, 2016; Sugiharto et al., 2016). This problem can be improving through an organized learning community.

Lesson Study (LS) is a model of educator professional development through the study of collaborative and sustainable learning, based on the principles of health to build a learning society. Through LS, four educator competencies can be increasing, namely; personality competence, social competence, professional competence, and pedagogical competence (Skott \& Møller, 2017; Susilo, 2013). After LS developed widely in Indonesia, this approach became a massive research study among researchers, and some of them claimed success. According to Setyawan, (2016); Sudirtha, (2017); R. E. Susetyarini, Wahyuni,
\& Latifa, (2015); Wahyuni, Susetyorini, \& Latifa, (2015) stating the integration of the implementation of lesson study in various learning models can improve students' thinking and learning skills. Next Lamb, (2015); Murtisal, Nurmaliah, \& Safrida, (2016) states that it can enhance pedagogical competence and teacher science process skills. Handayani, Ryskiadi, Machrus, \& Acik (2007), also noted that the application of lesson study could improve the teaching ability of prospective teachers.

Lesson study for learning community (LSLC), is also increasing in the practice of education in Indonesia, along with various studies, many researchers also believe that building LSLC contributes to helping schools in improving learning. On occasion ( $7^{\text {th }}$ International Conference on Lesson Study. University of Muhammadiyah Malang: 2-5 November 2016) shows the impact of the implementation of lesson study in schools has begun to be felting among lesson study participants. Some of the results of Indonesia's lesson study reports and reports show that there has been an increase in partner school participation and competency through learning lessons. Through the professional learning community raises natural abilities in solving learning problems (Flores Fahara, Rodríguez Bulnes, \& García Quintanilla, 2015; Munthe, Bjuland, \& Helgevold, 2016; Shepherd, 2019).

Other impacts of implementing LSLC were also found from teacher professional development through primary and secondary school training through city and district education offices (Nurwidodo et al., 2018). The implementation of LSLC is undoubtedly not easy for learning communities that are just starting. So, this study aims to assist in the implementation of Lesson study for the learning community. Starting from the implementation process of learning planning, the application of learning, and the implementation of reflection between teachers through collaborative practice.

\section{Method}

This research is a qualitative descriptive study that aims to provide an overview of Lesson Study Learning for Community assistance as a means of professional development for Senior high school biology teachers in Malang City. The subject of this study focuses on assisting 
the implementation of lesson study held between teachers SMA Negeri 4 Malang and Lecturers Faculty Teacher Training and Education University of Muhammadiyah Malang, as an effort to establish LSLC to improve the quality of learning for senior high school students through collegial, collaborative collaboration between teachers and lecturers. The number of LSLC participants involved were two teachers, four lecturers, and one LS expert who had different roles in LSLC involvement. The profile of LSLC participants can be seen in Table 1.

Table 1.Profile of Lesson Study for Learning Community participants State Senior High School 4 of Malang

\begin{tabular}{|c|c|c|}
\hline $\begin{array}{l}\text { Teachers/ } \\
\text { Lecturers }\end{array}$ & Gender & Experience \\
\hline Gunarta & Male & $\begin{array}{l}\text { Practitioner/model } \\
\text { teacher/observer }\end{array}$ \\
\hline Budi & Male & $\begin{array}{l}\text { Practitioner/model } \\
\text { teacher/observer }\end{array}$ \\
\hline Dwi & Male & $\begin{array}{l}\text { Practitioner/model } \\
\text { teacher/observer }\end{array}$ \\
\hline Tutut & Female & $\begin{array}{l}\text { Practitioner/model } \\
\text { teacher/observer }\end{array}$ \\
\hline Eko & Female & LSLC Expert \\
\hline Roimil & Female & $\begin{array}{l}\text { Practitioner/expert } \\
\text { companion/observer }\end{array}$ \\
\hline Zaenab & Female & $\begin{array}{l}\text { Practitioner/expert } \\
\text { companion/observer }\end{array}$ \\
\hline
\end{tabular}

This research approach uses case studies, which examine the phenomenon under review with two main questions; how and why (Bjuland \& Mosvold, 2015; Coenders \& Verhoef, 2019; Yin, 2018). This research approach uses a case study, which looks at the aspect examined by the study. This study lasted for four learning cycles, one cycle of two meetings, in each period, there was the plan, do, and see. The procedure for data collection is doing through; observation, interviews, and documentation focused on lesson study activities, at SMA Negeri 4 Malang. The means of representation are all lesson study activities from the lesson plan, open lesson, and reflection. Interviews are conducted in unstructured interviews, through free conversation and discussion activities in a planning forum or see the forum. The primary informants were teachers and lecturers who were directly involved and knew the lesson study process. Documentation in the form of lesson study documents is generating from teachers and lecturers in chapter design, lesson design, open lesson, observation sheets, refection discussion minutes, student worksheets (LKS), assignments done by students, and various other documents can provide data related to the focus of the research with two main questions.

\section{Results and Discussion}

\section{Implementation of lesson study for learning community (LSLC)}

\section{Workshop lesson study}

The first series of activities by conducting learning workshops. The workshop activity was beginning with the dissemination of the lesson study concept to teachers carried out at the University of Muhammadiyah Malang, which aimed to introduce LS by expert speakers and held discussions between researchers and teachers State Senior High School 4 of Malang. The material presented was about the implementation of Lesson Study, what was LSLC, how was the LSLC, how was the planning of the learning device, how was the application of LSLC (the task of the model teacher and observer), how to carry out reflection. After giving the material, the activity continued with brainstorming between teachers, as well as teachers with resource persons, about LSLC-based learning. The results of brainstorming are expected to be able to arouse the motivation of teachers to be willing and able to innovate, contemplate among fellow participants, and build commitment in the context of implementing LSLC-based learning. This activity is designing for one meeting at the beginning of the event. From this activity, the LS group produced, synchronized the implementation schedule of Lesson Study, open lesson, and the topic of learning that will be carried out during the LSLC mentoring that adapts to the school syllabus.

The initial stages in LSLC formation require a high commitment by the practitioners. Activities carried out collectively, require cooperative collegial teamwork. According to Nurwidodo et al., (2018); Rejeki, Humaira, Maryani, \& Nizar, (2018); Susetyarini \& Miharja, (2017) several things must be considered in the selection of the lesson study implementation team, among others; have shared hopes and goals, contribute to each other. Each team member must listen and focus on the problem, not on individuals, 
team members support each other and provide challenges, team members must fulfill their responsibilities individually, cooperate, maintain interaction and mutual respect, support independence, discipline, and fair (Coenders \& Verhoef, 2019). The full implementation of the Lesson Study for Learning Community program can be seen in Table 2.

Table 2. Implementation of the LSLC program at State Senior High School 4 of Malang

\begin{tabular}{cl}
\hline Implementation Date & Type of Activity \\
\hline July 11,2018 & $\begin{array}{l}\text { Coordination and } \\
\text { implementation of } \\
\text { LSLC }\end{array}$
\end{tabular}

Teams of teachers and lecturers meet with the

headmaster

The meeting is attending by all teams of teachers and lecturers who were assisted by the vice headmaster of the curriculum

Engagement of partner teachers across subjects, and subject teachers in the LSLC program by giving open invitations

\begin{tabular}{ll}
\hline July 18, 2018 & $\begin{array}{l}\text { Early stage planning } \\
\text { (determination of } \\
\text { activity schedule) }\end{array}$ \\
\hline July 18, 2018 & $\begin{array}{l}\text { Planning and } \\
\text { determining LS } \\
\text { activities }\end{array}$
\end{tabular}
Generate a plan, do, and see implementation schedule

Produce LS-based learning (Application of the PjBL model to improve critical and creative thinking skills through Lesson Study)

Produces Chapter Design and Lesson Plan Determination of teacher model for each cycle and invitation of the teacher as observer

\begin{tabular}{|c|c|c|}
\hline July 21, 2018 & Plan the first cycle & Assistance in implementing the plan. presentation of \\
\hline
\end{tabular}

\begin{tabular}{ll}
\hline July $23 \& 25,2018$ & Do, the first cycle \\
\hline July 25,2018 & See, the first cycle \\
\hline July 28,2018 & Plan, the second cycle
\end{tabular}
teacher, and improvement of LS steps/actions Do phase, the first cycle in class XI IPA 1 (Mr. Gunarta as a model teacher) See phase, of the first cycle in class XI IPA 1 and the submission of observer findings

Implementation plan assistance, presentation of planning results (Lesson Design) made by the model teacher, and improvement of LS improvement/action steps in the first cycle

\begin{tabular}{ll}
\hline $\begin{array}{l}\text { July } 30 \text { \& } \\
\text { August } 1,2018\end{array}$ & Do, the second cycle \\
\hline August 1,2018 & See, the second cycle \\
\hline August 4,2018 & Plan, the third cycle
\end{tabular}
Do Phase, the second cycle in class XI IPA 1 (Ms. Tutut as a model teacher) See phase, the second cycle in class XI IPA 1 and the submission of observer findings

Implementation plan assistance, presentation of planning results (Lesson Design) made by the model teacher, and improvement of LS improvement/action steps in the second cycle

\begin{tabular}{lll}
\hline August $6 \&$ 8, 2018 & Do, the third cycle & $\begin{array}{l}\text { steps in the second cycle } \\
\text { Do model teacher) }\end{array}$ \\
\hline august 8, 2018 & See, the third cycle & $\begin{array}{l}\text { See phase, of the third cycle in class XI IPA 1 and the } \\
\text { submission of observer findings }\end{array}$ \\
\hline August 11, 2018 & Plan, the fourth cycle & $\begin{array}{l}\text { Implementation plan assistance, presentation of } \\
\text { planning results (Lesson Design) made by the model } \\
\text { teacher, and improvement of LS improvement/action } \\
\text { steps in the third cycle }\end{array}$ \\
\hline August 13 \& 15, 2018 & Do, the fourth cycle & $\begin{array}{l}\text { Do phase, the fourth cycle in class XI IPA 1 (Mrs. Rr. } \\
\text { Eko as a model teacher) }\end{array}$ \\
\hline August 15, 2018 & See, the fourth cycle & $\begin{array}{l}\text { See phase, the fourth cycle in class XI IPA 1 and the } \\
\text { submission of observer findings }\end{array}$ \\
\hline September 13, 2018 & $\begin{array}{l}\text { Making learning video } \\
\text { base on LS }\end{array}$ & $\begin{array}{l}\text { Editing video of the plan, do and see activities that } \\
\text { have been doing }\end{array}$ \\
\hline
\end{tabular}

\section{Planning assistance (Plan), collaborative practice learning tools in LSLC}

The implementation of the Lesson Study-based learning workshop with collaborative practice was implementing with the activity of compiling learning tools by participants in the form Lesson plan (RPP) based on LS. In the process of preparing the learning device, the teacher will get maximum mentoring from the accompanying team. One teacher will get a model lecturer partner, each of whom receives an LSLC expert companion. The mentoring schedule is adjusting to the 
school agenda. While the meeting between teachers is planning to be conducted in eight sessions.

The results of this assistance are one chapter design and four Lesson designs for all LS cycles. Focus on improving student learning, namely, collaborative practicebased learning. The results of monitoring plan activities in assistance LSLC can be seen in Table 3.

Table 3. The results of monitoring plan activities in assistance LSLC

\begin{tabular}{lcc}
\hline \multicolumn{1}{c}{ Kegiatan Peserta } & Yes & No \\
\hline Is the purpose of the meeting discussed? & Yes & - \\
Is the teacher's model determined at the meeting? & Yes & - \\
Do model lecturers compile lesson designs? & Yes & - \\
If the model teacher arranges the lesson design, are lesson designs discussed at the meeting? & Yes & - \\
Does the teacher model research the practice of Lesson Study (determine the research theme, & Yes & - \\
focus of the research, or the primary purpose of the study)? & Yes \\
Are lesson designs arranged together at meetings? & Yes \\
Are the learning objectives discussed in lesson design discussed? & - \\
Is the apperception discussed that will be talking when opening the lesson? & Yes \\
Is the learning method/strategy to be used discussed? & Yes \\
Is the learning media discussed to be used? & Yes \\
Is the learning material discussed that will be discussing in the learning process? & Yes \\
Is time management discussed in the learning process? & Yes \\
Is the type of evaluation discussed in the learning process discussed? & Yes \\
Are evaluation instruments discussed that will be using in the learning process? & - \\
Was collegiality created during the discussion? & Yes \\
\hline
\end{tabular}

The results of monitoring the LSLC planning activities from Table 2, show that teachers and lecturers can visualize planning activities; as evidenced by the involvement of teachers and lecturers in explaining meeting objectives. Determining teacher models, learning topics, lesson design, learning objectives, apperception activities, methods, strategies, learning media, time management, type of evaluation, evaluation instruments, perceive one hypothesis and solution based on problems that arise from the initial observation of the class before the Lesson Study stage is carried out. All teams are involved and contribute actively in achieving the implementation of Lesson Study. According to Manrulu \& Sari, (2015); Murtisal et al., (2016); Wood \& Cajkler, (2016), efforts to improve learning through lesson study must be supported by useful pedagogical competence so that it can be using as a means of learning and improving the quality of teaching resources.

The creation of collegiality between teachers and lecturers in LSLC activities is shown through discussion, analyzing, expressing opinions made by teachers and lecturers in designing learning by learning from each other, and education. This is directly proportional to the results of the study Lamb, (2015); Manrulu \& Sari, (2015); Shepherd, (2019); Skott \& Møller, (2017) explained that each has a different idea of the method and delivery of material in shaping the competence of students, while collaboration in discussion groups between lecturers is very supportive in designing a learning, as well as building knowledge where lecturers will learn from other lecturers. While Flores Fahara et al., (2015); E. Susetyarini \& Miharja, (2017), in his research explained the teachers acknowledged the fact that; 1) the teacher can learn from his colleagues, 2) the learning community is an opportunity for novice teachers to learn from expert teachers and vice versa, and 3) the learning community in the process allows teachers to create projects together and experience a sense of community.

\section{Assistance in the application of biology learning "Do" with collaborative learning based on LSLC}

After lesson design and collaborative learning design chapters are compiling, the teacher is asked to do classroom learning with one model teacher and several observers. When implementing learning, the focus of improvement is the ability to think critically and creatively by discussing biological practices. The practice of learning is conducted eight times each meeting (four cycles); the implementation schedule is adjusting to the teacher's program at school. The results of monitoring "Do" activities in assistance LSLC can be seen in Table 4 . 
Table 4. The results of monitoring "Do" activities in Assistance LSLC

\begin{tabular}{|c|c|c|}
\hline Participant Activities & Yes & No \\
\hline $\begin{array}{l}\text { Before the activity is carried out, is there a learning device that is ready for use, such as; } \\
\text { Lesson design, LKS, hand out, and supporting facilities? }\end{array}$ & Yes & - \\
\hline Does the teacher appear according to the agreement? & Yes & - \\
\hline Does the model teacher appear independently (not the team)? & Yes & - \\
\hline $\begin{array}{l}\text { Does the teacher associate the material that has been thinking with the learning } \\
\text { activities that will be implementing? }\end{array}$ & Yes & - \\
\hline Does the teacher model discuss learning objectives? & Yes & - \\
\hline Does the teacher model provide apperception in learning? & Yes & - \\
\hline Does the teacher model provide correct answers to student questions? & Yes & - \\
\hline $\begin{array}{l}\text { Does the teacher model dare to change the design lesson in implementing learning } \\
\text { following the learning situation that occurs? }\end{array}$ & - & No \\
\hline Does the teacher model use learning media following lesson design? & Yes & - \\
\hline Does the use of time match the time allocation in lesson design? & Yes & - \\
\hline $\begin{array}{l}\text { Do the observer's activities interfere with the implementation of learning; position } \\
\text { blocking the camera, behind the class, observer mobility, observer interaction, } \\
\text { seriousness? }\end{array}$ & Yes & - \\
\hline Are there observers who help students? & Yes & - \\
\hline In general, do the observers make observations according to the rules? & - & No \\
\hline $\begin{array}{l}\text { Is the activity observed, prioritized by the model and observer teacher in Lesson Study } \\
\text { an activity of student learning? }\end{array}$ & Yes & - \\
\hline
\end{tabular}

The results of monitoring the learning activities (Do) in LSLC activities in Table 4 have indicated planned activities. One member acted as a model teacher, and the other members as observers agreed. The focus of the observation is directing directed at student learning activities, with observation instruments from planning activities (plan). However, in this activity there were still observers' activities that were not in accordance with their work standards, including; 1) the activities of the observer disrupted the implementation of the learning (the position of blocking the camera, behind, the mobility of the observer, the interaction of the observer, seriousness), 2) the activity of the observer assisting the students in learning, and 3) the observer making observations not in accordance with the rules.

Lesson study activities have three implementing components, namely model teacher/lecturer, observer, and cameraman. These three components collaborate, namely collaborating, to do their respective tasks to get better results according to the plan. The job of observers should be to observe student learning activities, observe and record each student's response to learning activities that are not following the learning plan (Dudley, 2014; Wood \& Cajkler, 2016). The observer should carry out its function without intervening in the ongoing learning, not talking to each other observer, and taking positions that do not interfere with the learning process. So, in the lesson study activities besides determining the class plan for learning activities, it must also determine the observer's work area. According to the study Pramudiyanti et al. (2017), improvement in observer lesson study skills is influenced by; 1 ) the observer must know the stages of lesson study and the things done by the team at each stage; 2) the observer must know the limitations of the observer's assignments in lesson study; 3) observers must know how to use instruments that are used to observe the behavior of students who are studying.

\section{Reflection activities (see), biology learning in LSLC}

Reflection Activity (See). After doing classroom teaching, the model teacher and some observers reflect on the results of the observation. The findings discussed are the way students learn, the quality of student learning, and the way students get an independent understanding of their learning activities. Reflection is doing according to the number of cycles in learning. The results of monitoring reflection activities in assisting LSLC activities can be seen in Table 5 .

The results of the implementation of reflection see from the observation sheet and documents during the reflection activity. Based on Table 5, in reflection activities (see) shows the effectiveness of reflection activities carried out by the LSLC team. It was proved by the activities of teachers and lecturers involved as model teachers and observers who were able to report the results of observations based on concrete and specific evidence. The results 
of good reflection must be supported by observation instruments from the model teacher and observer who can represent any categories observed and ease the explanation of findings, from learning activities to improvement patterns that must be explained by the model teacher or observer.

Table 5. The results of monitoring reflection activities in assisting LSLC

\begin{tabular}{lcc}
\hline \multicolumn{1}{c}{ Participant Activities } & Yes & No \\
\hline Does the moderator introduce the lesson study team? & Yes \\
Did the moderator convey the arrangement of the program? & Yes & - \\
Does the moderator convey an outline of reflection rules? & Yes \\
Does the moderator give the model teacher the first opportunity to convey self-reflection? & Yes & - \\
Are there observers who share their own experiences? & Yes & - \\
Are all observers allowed to speak? & Yes & - \\
Are observer comments based on concrete and specific evidence? & Yes & - \\
Are the observer's comments more positive? & Yes & - \\
Are the observer comments more negative towards the model teacher? & No \\
Are there solutive and constructive suggestions? & Yes & - \\
Are there observers who submit comments according to their views? & Yes & - \\
Is the discussion-reflection activity dominated by someone or just a few people? & - & No \\
Can the teacher/lecturer who teaches receive suggestions for improvement? & Yes & - \\
Are observer comments focused on learning activities? & Yes & - \\
Do observer comments focus on learning material? & - & No \\
Do observer comments focus on the way lecturers teach? & - & No \\
Does the reflection event take place according to the planned program schedule? & Yes & - \\
\hline
\end{tabular}

The fact shows that reflection activities have led to an increase in the quality of learning, and no negative responses have been finding for the model teacher. The decline in adverse reactions to teacher models can be categorizing as a reflection process that has led to the achievement of the details of the learning process, observers and model teachers are more focused on expressing their findings, leading to evaluation, revealing appropriate solutions to the problems found. In line with the results of the study Bozkurt \& Özdemir, (2018) that reflection activities must provide benefits and encourage teachers to make detailed and reliable evaluations, contribute to controlled cause and effect findings, and productive conclusions for their teaching.

Reflections that are carrying out do not only meet the lesson study stage. The results of observation have been well documented, this is because there are adequate reflection guidelines for the means of improving the quality of effective learning. In line with the study Laelawati, Sriyanti, \& Rochintaniawati, (2016) that is the reflection guide also influenced the implementation of observer activities. The reflection guide should make it easier for the teacher to present his findings when learning can be reading well and his tendency to facilitate the model teacher as seen from the results of filling out the guidance sheet, especially in identifying student learning indicators.

\section{Other findings in the implementation of LSLC in State Senior High School 4 of Malang}

The involvement of teachers and lecturers in the practice of LSLC shows a fairly professional effort, although it can be admitting that the members involved are still few. The implementation of LSLC at SMA Negeri 4 Malang is a new pilot project. The formation of the Lesson Study group was initiated by teachers and lecturers who had been practitioners. The recruitment of its members is based on the involvement of teachers in the research of lecturers, teachers who are voluntary in improving their competence, and the absence of other partner schools. The obstacle that arises and must be a concern is the sustainability of LSLC in the future. In line with the results of the study Nurwidodo et al., (2018) explaining that LSLC materializes and becomes successful, by increasing resources and utilizing partnerships with schools it is essential, in collaboration with schools to implement LSLC, both parties must share the same needs, who face challenges with willingness to work together to solve problems .

Lesson study requires full involvement at each stage. The implementation of the plan, do and see phases in the practice of LSLC in SMA Negeri 4 Malang can be doing well. Making commitments and rules of the game to synchronize schedules can be an obstacle, with members consisting of 
teachers and lecturers, it is not possible for each other's activities to become obstacles to being involved in several stages of lesson study. In line with the results of the study Flores Fahara et al., (2015) states that another problem that arises as part of the lesson study is the time constraints faced by teachers because of their busy schedules, which can stop their desire to be involved in it. More than that, schools have not made lesson study as part of learning, so lesson study has not yet fully become an effort to assist teacher professionalism in providing opportunities to increase their competence.

\section{Conclusion}

Based on the results of the research, it was found that the implementation of LSLC had been going well. This could be seen in the three stages of lesson study; plan, do, and see in the monitoring sheet showed conformity, although at the "Do" phase there were still observers who worked not following their task procedures, and the involvement of teachers in LSLC activities was still small. Through the results of this study, it was obtained collegial between teachers and lecturers, which can be seen in determining the themes of learning, learning plans, and corrective actions from the results of discussions, and learning from each other. Teachers and lecturers can also visualize abilities in planning, manage problems, make decisions based on hypotheses, solve problems, and reflect on their various practical teaching experiences. Based on the conclusions, the suggestions that can be proposing are that LSLC activities are sustainable, so further assistance is needed in the stage of learning through lesson study, teacher involvement in LSLC activities should be increased by adding participants from teachers across subjects, and making observer skills training programs in activities LSLC in the future.

\section{Acknowledgment}

The author on this occasion expressed his gratitude to Faculty of Teacher Training and Education, the University of Muhammadiyah Malang in supporting research funding, teachers State Senior High School 4 of Malang, and lecturer's biology education department involved in the research, hopefully, recorded as good deeds by Allah SWT.

\section{References}

Bjuland, R., \& Mosvold, R. (2015). Lesson study in teacher education: Learning from a challenging case. Teaching and Teacher Education, 52 (June 2017), 83-90. https://doi.org/ 10.1016/j.tate.2015.09.005

Bozkurt, E., \& Özdemir, İ. E. Y. (2018). Middle school mathematics teachers' reflection activities in the context of lesson study. International Journal of Instruction, 11(1), 379-394. https://doi.org/ 10.12973/iji.2018.11126a

Coenders, F., \& Verhoef, N. (2019). Lesson study: professional development (PD) for beginning and experienced teachers. Professional Development in Education, 45(2), 217-230. https://doi.org/10.1080/19415257. 2018.1430050

Delvaux, E., Vanhoof, J., Tuytens, M., Vekeman, E., Devos, G., \& Van Petegem, P. (2013). How may teacher evaluation have an impact on professional development? a multilevel analysis. Teaching and Teacher Education, 36, 1-11. https://doi.org/10.1016/j.tate.2013. 06.011

Dudley, P. (2014). Lessonstudy a handbook. Retrieved from http://lessonstudy. co.uk/wp-content/uploads/2012/ 03/new-handbook-revisedMay14.pdf

Flores Fahara, M., Rodríguez Bulnes, M. G., \& García Quintanilla, M. (2015). Building a professional learning community: a way of teacher participation in mexican public elementary schools. International Journal of Educational Leadership and Management, 3(2), 113. https://doi.org/10.17583/ijelm.201 5.1338

Handayani, R. D., Ryskiadi, A., Machrus, A., \& Acik, R. (2007). Penerapan lesson study untuk meningkatan kemampuan mengajar mahasiswa calon guru fisika. Jurnal Pengajaran MIPA, 20(1), 27-31. https://doi.org/10.18269/jpmipa.v 20 i1.558 
Laelawati, S., Sriyanti, S., \& Rochintaniawati, D. (2016). Pengembangan model refleksi pada lesson study untuk meningkatkan kualitas pembelajaran IPA di sekolah. Seminar Nasional Pendidikan Dan Saintek: Isu-Isu Kontemporer Sains, Lingkungan, Dan Inovasi Pembelajarannya, 809-813. Retrieved from https://publikasiilmiah.ums.ac.id/b itstream/handle/11617/8018/121.p df? sequence $=1$

Lamb, P. (2015). Peer-learning between preservice teachers: embracing Lesson Study. International Journal for Lesson and Learning Studies, 4(4), 343-361. https://doi.org/10.1108/ IJLLS-03-2015-0012

Manrulu, R. H., \& Sari, D. N. (2015). Efektivis kegiatan lesson study dalam merancang pembelajaran pada mata kuliah gelombang dan optik. Jurnal Ilmiah Pendidikan Fisika Al-Biruni, 4(2), 231. https://doi.org/10.24042/jpifalbiru ni.v4i2.95

Munthe, E., Bjuland, R., \& Helgevold, N. (2016). Lesson study in field practice: a time-lagged experiment in initial teacher education in Norway. International Journal for Lesson and Learning Studies, 5(2), 142-154. https://doi.org/10.1108/ IJLLS-12-2015-0047

Murtisal, E., Nurmaliah, \& Safrida, C. (2016). Implementasi pembelajaran berbasis lesson study terhadap kompetensi pedagogik dan keterampilan proses sains guru biologi SMA Negeri 11 dan MA Negeri 3 Kota Banda Aceh. Jurnal Biotik, 4(1), 81-94. Retrieved from http://jurnal.ar-raniry.ac.id/index. php/biotik/article/download/1074/ 844

Nurwidodo, N., Hendayana, S., Hindun, I., \& Sarimanah, E. (2018). Strategies for establishing networking with partner schools for implementing lesson study in Indonesia. Jurnal Pendidikan Biologi Indonesia, 4(1), 11-22. https://doi.org/10.22219/ jpbi.v4i1.5489

Pramudiyanti, P., Susilo, H., Hastuti, U. ., Lestari, U., Zakia, A., Pangastuti, R., \& Jannati, P. (2017). Peningkatan keterampilan observer dan kameramen dalam kegiatan lesson study pada pembelajaran biologi sel. Prosiding Seminar Nasional Pendidikan MIPA FKIP Universitas Lampung, (October), 179-187. Retrieved from https://www.researchgate.net/profi le/Pramudiyanti_Pramudiyanti/publ ication/322600143_peningkatan_ke terampilan_observer_dan_kameram en_dalam_kegiatan_lesson_study_p ada_pembelajaran_biologi_sel/links /5a61f443a6fdccb61c504f41/penin gkatan-keterampilan-observer

Rejeki, S., Humaira, Maryani, S., \& Nizar. (2018). Lesson study for learning community (LSLC): pengalaman berharga dalam pengelolaan pembelajaran secara terbuka. 1(1), 54-60. Retrieved from http://jurnal.umk.ac.id/index.php/pend as/article/download/2318/1346

Sato, M. (2012). Reformasi pembelajaran dengan learning community dan pengembangan sekolah kreasi pendidikan model abad ke-21. International Lesson Study Conference. Retrieved from https://www.jica.go.jp/project/indo nesian/indonesia/0800042/.../mate rials_01.docx

Setyawan, D. (2016). Penerapan model pembelajaran inquiri berbasis lesson study untuk meningkatkan kemampuan berfikir kritis dan hasil belajar pada matakuliah pengetahuan lingkungan program studi pendidikan biologi universitas muhammadiyah malang. Proceeding International Conference on Lesson Study (ICLS), (3-5 November), 44-50. Retrieved from http://researchreport.umm.ac.id/index.php/resear ch-report/article/download/1945/ 2028

Shepherd, A. V. (2019). Integrating lesson study in Myanmar teacher training. International Journal for Lesson and Learning Studies, 8(1), 34-47. https://doi.org/10.1108/IJLLS-042018-0024

Skott, C. K., \& Møller, H. (2017). The individual teacher in lesson study collaboration. International Journal for Lesson and Learning Studies, 6(3), 216-232. https://doi.org/ 10.1108/IJLLS-10-2016-0041 
Sudirtha, I. G. (2017). Membangun learning community dan peningkatkan kompetensi melalui lesson study. JPI (Jurnal Pendidikan Indonesia), 6(1), 28-38. https://doi.org/ 10.23887/jpi-undiksha.v6i1.8683

Sugiharto, B., Prayitno, B. A., \& Widoretno, S. (2016). Jenis pengembangan keprofesian dan konsepsi terhadap lesson study learning community pada guru IPA SMP Kota Surakarta. Prosiding Biology Education Conference, 13(1), 63-69. Retrieved from https://jurnal.uns.ac.id/prosbi /article/view/5654/5022

Susetyarini, E., \& Miharja, F. J. (2017). The implementation of lesson studylearning community for prospective biology teacher. International Journal of Advanced Research (IJAR), 5(10), 1228-1235. https://doi.org/10.21474/IJAR01/5 641

Susetyarini, R. E., Wahyuni, S., \& Latifa, R. (2015). Kemampuan berpikir kritis mahasiswa pada matakuliah embriologi dan reproduksi hewan melalui lesson study. Prosiding Seminar Nasional Pendidikan Biologi 2015, 774-781. Retrieved from http://research-

report.umm.ac.id/index.php/resear ch-report/article/view/520/744

Susilo, H. (2013). lesson study sebagai sarana meningkatkan kompetensi pendidik. Seminar Dan Lokakarya: Lifelong Learning for Ministers, 132. Retrieved from http://sttaletheia.ac.id/wp-content/ uploads/2013/07/Lesson-StudySebagai-Sarana-MeningkatkanKompetensi-Pendidik-herawati.pdf

Wahyuni, S., Susetyorini, R. E., \& Latifa, R. (2015). Peningkatan kemampuan berpikir kritis mahasiswa pendidikan biologi UMM melalui lesson study. JINoP (Jurnal Inovasi Pembelajaran), 1(2), 187-200. https://doi.org/10.22219/jinop.v1i 2.2571

Wood, P., \& Cajkler, W. (2016). A participatory approach to Lesson Study in higher education. International Journal for Lesson and Learning Studies, 5(1), 4-18. https://doi.org/10.1108/IJLLS-082015-0027

Yin, R. K. (2018). Studi Kasus: Desain \& Metode (15th ed.). Jakarta: Rajawali Press. 